\title{
Saccharopolyspora cebuensis sp. nov., a novel actinomycete isolated from a Philippine sponge (Porifera)
}

\author{
Correspondence \\ Ute Hentschel \\ ute.hentschel@mail.uni- \\ wuerzburg.de
}

\author{
Sheila Marie Pimentel-Elardo, ${ }^{1,2}$ Loralie P. Tiro, ${ }^{2}$ Lubomir Grozdanov ${ }^{1}$ \\ and Ute Hentschel ${ }^{1}$
}

\author{
${ }^{1}$ Research Center for Infectious Diseases, University of Würzburg, Röntgenring 11, \\ D-97070 Würzburg, Germany \\ ${ }^{2}$ College of Pharmacy, University of San Carlos, Cebu City 6000, Philippines
}

\begin{abstract}
The taxonomic status of a marine actinomycete isolated from the sponge Haliclona sp. collected from Cebu, Philippines, was established using both phenotypic and genotypic data. Strain SPE 10-1 ${ }^{\top}$ exhibited chemotaxonomic and morphological characteristics that were consistent with those of members of the genus Saccharopolyspora. It showed a strict requirement for salt and is the first obligate marine bacterium of the genus Saccharopolyspora to be isolated. The principal isoprenoid quinone detected was $\mathrm{MK}-9\left(\mathrm{H}_{4}\right)$. The fatty acid pattern consisted mainly of terminally branched iso and anteiso fatty acids. The DNA G+C content was $72.6 \mathrm{~mol} \%$. Analysis of the 16S rRNA gene sequence supported affiliation of the strain with the genus Saccharopolyspora; the type strain of Saccharopolyspora gregorii was the closest phylogenetic relative (96\% sequence similarity). Sequence similarities of strain SPE $10-1^{\top}$ to other type strains of this genus were $93-95 \%$. It is proposed that strain SPE $10-1^{\top}$ should be classified in the genus Saccharopolyspora as a representative of Saccharopolyspora cebuensis sp. nov. The type strain of Saccharopolyspora cebuensis is SPE $10-1^{\top}\left(=\mathrm{DSM} 45019^{\top}=\mathrm{CIP} 109355^{\top}\right)$.
\end{abstract}

The genus Saccharopolyspora was first described by Lacey \& Goodfellow (1975) and at present comprises ten species with validly published names: Saccharopolyspora hirsuta (Lacey \& Goodfellow, 1975), Saccharopolyspora erythraea (Labeda, 1987), Saccharopolyspora taberi (Korn-Wendisch et al., 1989), Saccharopolyspora gregorii (Goodfellow et al., 1989), Saccharopolyspora hordei (Goodfellow et al., 1989), Saccharopolyspora rectivirgula (Korn-Wendisch et al., 1989), Saccharopolyspora spinosa (Mertz \& Yao, 1990), Saccharopolyspora spinosporotrichia (Zhou et al., 1998), Saccharopolyspora flava ( $\mathrm{Lu}$ et al., 2001) and Saccharopolyspora thermophila (Lu et al., 2001). Members of this genus are aerobic, Gram-positive, non-acid-fast organisms with substrate hyphae that either fragment into rod-shaped elements, do not fragment or are transformed partially into chains of spores (Korn-Wendisch et al., 1989). They lack mycolic acid, but contain meso-diaminopimelic acid, arabinose and galactose in the cell wall and predominantly tetrahydrogenated menaquinones with nine isoprene units. The DNA G $+\mathrm{C}$ contents for type strains of species of the genus fall within the range $67-74 \mathrm{~mol} \%$

Abbreviation: ASW, artificial seawater.

The GenBank/EMBL/DDBJ accession number for the $16 \mathrm{~S}$ rRNA gene sequence of strain SPE $10-1^{\top}$ is EF030715.
(Embley et al., 1987; Goodfellow et al., 1989; KornWendisch et al., 1989).

In this study, cultivation and characterization of strain SPE $10-1^{\mathrm{T}}$, a marine sponge isolate that exhibits properties consistent with its assignment to the genus Saccharopolyspora, are described.

Strain SPE $10-1^{\mathrm{T}}$ was isolated from the marine sponge Haliclona sp. on M1 agar. M1 medium, which is specifically designed for the isolation of marine actinomycetes, is composed of the following [per litre artificial seawater (ASW)]: $10 \mathrm{~g}$ starch, $4 \mathrm{~g}$ yeast extract and $2 \mathrm{~g}$ peptone (Mincer et al., 2002). ASW contains the following salts $\left(\mathrm{l}^{-1}\right): 23.477 \mathrm{~g} \mathrm{NaCl}, 10.64 \mathrm{~g} \mathrm{MgCl}_{2} .6 \mathrm{H}_{2} \mathrm{O}, 3.917 \mathrm{~g}$ $\mathrm{Na}_{2} \mathrm{SO}_{4}, 1.102 \mathrm{~g} \mathrm{CaCl}_{2}, 0.664 \mathrm{~g} \mathrm{KCl}, 0.192 \mathrm{~g} \mathrm{NaHCO}_{3}$, $0.096 \mathrm{~g} \mathrm{KBr}, 0.026 \mathrm{~g} \mathrm{H}_{3} \mathrm{BO}_{3}, 0.024 \mathrm{~g} \mathrm{SrCl}_{2}$ and $0.03 \mathrm{~g} \mathrm{NaF}$ (Lyman \& Fleming, 1940). The sponge was collected by scuba diving off Maribago waters (GPS: $10^{\circ} 17^{\prime} 0.97^{\prime \prime} \mathrm{N}$ $124^{\circ} 00^{\prime} 01.8^{\prime \prime}$ E), Cebu, Philippines, in February 2003. Mechanical separation of the sponge tissue and bacterial isolation were performed as described by Pimentel-Elardo et al. (2003).

Growth on M1 broth was tested at 10, 15, 20, 25, 30, 37, 45 and $55{ }^{\circ} \mathrm{C}$. Strain SPE $10-1^{\mathrm{T}}$ was able to grow between 15 and $37{ }^{\circ} \mathrm{C}$, with optimal growth at $25-30{ }^{\circ} \mathrm{C}$. Colonies displayed chalky-white mycelia with brownish soluble 
pigment on M1 agar. Cultures of strain SPE $10-1^{\mathrm{T}}$ grown in M1 broth for 7-14 days appeared yellowish-brown to brown in colour. Strain SPE $10-1^{\mathrm{T}}$ was capable of growing in ISP2 medium (Shirling \& Gottlieb, 1966) $\left(1^{-1}: 4\right.$ g yeast extract, $8 \mathrm{~g}$ malt extract and $4 \mathrm{~g}$ glucose) in ASW, as well as in Zobell marine medium (Oppenheimer \& ZoBell, 1952) $\left(1 \mathrm{~g}\right.$ yeast extract $\mathrm{l}^{-1}, 5 \mathrm{~g}$ peptone $\mathrm{l}^{-1}, 250 \mathrm{ml}$ distilled water, $750 \mathrm{ml}$ ASW). Strain SPE $10-1^{\mathrm{T}}$ did not grow in ISP2 medium without ASW. No growth was observed on M1 agar plates incubated in an anaerobic jar. M1 media supplied with different amounts of ASW or $\mathrm{NaCl}$ were used to test for the requirement for seawater and salt tolerance. Growth was possible in regular strength M1 (100\% ASW) and in M1 containing 75, 50 and $25 \%$ ASW, but not $0 \%$ ASW. Growth was also possible when regular strength ASW was replaced with $12.5,10.0,7.5$ or $5.0 \%$
$\mathrm{NaCl}$ in distilled water. Growth was poor in $\mathrm{M} 1$ with $2.5 \%$ $\mathrm{NaCl}$ and growth was not observed without $\mathrm{NaCl}$ or with $15 \% \mathrm{NaCl}$. From these data, it is concluded that strain SPE $10-1^{\mathrm{T}}$ has a strict requirement for salt, which suggests that it is an obligate marine bacterium. Furthermore, strain SPE $10-1^{\mathrm{T}}$ was able to grow in M1 liquid medium supplemented with the antibiotics $\left(100 \mu \mathrm{g} \mathrm{ml}^{-1}\right)$ gentamicin and kanamycin, but not with rifampicin, penicillin, streptomycin, lincomycin, vancomycin, oxacillin, chloramphenicol, ampicillin or tetracycline.

For phenotypic testing, API identification kits (bioMérieux) were used. Strain SPE $10-1^{\mathrm{T}}$ was grown in M1 agar for $72 \mathrm{~h}$ and resuspended in ASW. Data on growth on different carbon sources were obtained using the API $\mathrm{CH}$ system and are given in the species description.

Table 1. Selected physiological properties of strain SPE $10-1^{\top}$ and the type strains of the species of the genus Saccharopolyspora

Strains: 1, SPE $10-1^{\mathrm{T}} ; 2$, S. gregorii DSM $44324^{\mathrm{T}} ; 3$, S. spinosporotrichia DSM 44350 ${ }^{\mathrm{T}} ; 4$, S. spinosa DSM 44228 ${ }^{\mathrm{T}} ; 5$, S. erythraea DSM 40517 ${ }^{\mathrm{T}} ; 6$, S. hirsuta subsp. hirsuta DSM $43463^{\mathrm{T}}$; 7, S. hordei DSM $44065^{\mathrm{T}} ; 8$, S. rectivirgula DSM 43747 $7^{\mathrm{T}}$; 9, S. flava AS4.1520 ${ }^{\mathrm{T}}$; 10, S. thermophila AS4.1511 ${ }^{\mathrm{T}}$; 11 , S. taberi DSM $43856^{\mathrm{T}}$. Data for strain SPE $10-1^{\mathrm{T}}$ are from this study; data for all other strains are from Lu et al. (2001), except for data on hypoxanthine, DNA G + C content and D-mannitol utilization which are from Goodfellow et al. (1989), Labeda (1987), Lacey \& Goodfellow (1975), Mertz \& Yao (1990) and Zhou et al. (1998). BF, Buff; BR, brown; C, colourless; G, grey; O, orange; P, pink; R, red; W, white; Y, yellow; +, positive; -, negative; NA, no aerial mycelium; ND, not determined. All Saccharopolyspora strains were positive for utilization of D-fructose, glycerol and Dmannose as sole carbon source.

\begin{tabular}{|c|c|c|c|c|c|c|c|c|c|c|c|}
\hline Characteristic & 1 & 2 & 3 & 4 & 5 & 6 & 7 & 8 & 9 & 10 & 11 \\
\hline \multicolumn{12}{|l|}{ Utilization of: } \\
\hline L-Arabinose & + & + & - & + & + & - & + & - & - & - & - \\
\hline D-Lactose & + & - & - & - & - & + & + & + & + & + & + \\
\hline Maltose & + & + & + & - & + & + & + & + & + & + & + \\
\hline D-Mannitol & - & + & + & + & + & + & + & + & + & + & + \\
\hline L-Rhamnose & + & + & + & - & + & + & + & + & + & + & + \\
\hline Sucrose & + & + & + & - & + & + & + & + & + & + & + \\
\hline D-Xylose & + & + & + & - & + & + & + & + & + & - & + \\
\hline \multicolumn{12}{|c|}{ Temperature range for } \\
\hline Nitrate reduction & - & - & - & + & + & - & - & + & + & - & + \\
\hline Chitin & - & - & - & - & + & - & + & - & - & - & + \\
\hline Hypoxanthine & - & + & + & + & + & + & + & + & + & - & + \\
\hline Tyrosine & + & + & - & + & + & + & + & + & - & + & + \\
\hline \multicolumn{12}{|l|}{ Colour of mycelia: } \\
\hline Aerial & $\mathrm{W} \ddagger$ & $\mathrm{W}-\mathrm{Y}$ & $W-G$ & $\mathrm{~W}-\mathrm{P}$ & $\mathrm{P}-\mathrm{BRG}-\mathrm{W}$ & $\mathrm{W}$ & $\mathrm{W}-\mathrm{Y}$ & W-light P & $\mathrm{W}$ & $\mathrm{W}$ & NA \\
\hline Substrate & $w \ddagger$ & $\mathrm{C}-\mathrm{BF}$ & $B R-R$ & $\mathrm{G}-\mathrm{OY}-\mathrm{BR}$ & OY-RBR & $\mathrm{C}-\mathrm{BF}$ & $\mathrm{C}-\mathrm{BF}$ & $\mathrm{Y}-\mathrm{O}$ & Y & $\mathrm{C}-\mathrm{BF}$ & $\mathrm{C}-\mathrm{Y}$ \\
\hline $\begin{array}{l}\text { DNA G }+ \text { C content } \\
(\mathrm{mol} \%)\end{array}$ & 72.6 & 74.0 & 70.4 & ND & 71.1 & 71.5 & 72.0 & 70.4 & 67.0 & 73.1 & 70.8 \\
\hline
\end{tabular}

*The temperature data from Lu et al. (2001) for the type strains differ slightly from those of Korn-Wendisch et al. (1989) who reported a temperature range of $20-50{ }^{\circ} \mathrm{C}$ for $S$. hirsuta and $37-60{ }^{\circ} \mathrm{C}$ for S. rectivirgula species.

$\dagger$ Strain SPE $10-1^{\mathrm{T}}$ is the only known isolate with a strict requirement for salt.

¥Note that the ISP2 medium was supplemented with ASW and that mycelial colour may vary depending on media composition. 
Strain SPE $10-1^{\mathrm{T}}$ was positive for the following enzymes using the API ZYM system: alkaline phosphatase, esterase (C4), esterase lipase (C8), lipase (C14), leucine arylamidase, valine arylamidase, acid phosphatase, naphthol-ASBI-phosphohydrolase, $\alpha$-glucosidase, $N$-acetyl- $\beta$-glucosaminidase and $\alpha$-mannosidase. The ability to degrade macromolecules was determined using the method of Korn-Wendisch et al. (1989). The strain was able to degrade tyrosine, but not adenine, casein, chitin or hypoxanthine. Furthermore, strain SPE $10-1^{\mathrm{T}}$ stained Gram-positive and was catalase-positive (standard hydrogen peroxide reaction). Strain SPE $10-1^{\mathrm{T}}$ tested negative for oxidase activity and for reduction of nitrate to nitrite using established procedures (Gordon, 1967; MacFaddin, 1980). The organism could be distinguished from the type strains of other species of the genus Saccharopolyspora by using a combination of phenotypic properties (Table 1).

Determination of the following diagnostic cell-wall components and $\mathrm{G}+\mathrm{C}$ content of the genomic DNA were performed by the DSMZ, Braunschweig, Germany. Established procedures were used to determine diagnostic diaminopimelic acid isomers and the predominant sugars of the whole organism (Staneck \& Roberts, 1974). Quinone analysis was carried out as described by Kroppenstedt (1985). The presence of mycolic acids was investigated following the procedure of Minnikin et al. (1975). Polar lipids were extracted and analysed following the integrated procedure of Minnikin et al. (1984). The fatty acid content was determined by GC using MIDI software. The genomic DNA $\mathrm{G}+\mathrm{C}$ content was determined by HPLC (Mesbah et al., 1989; Tamaoka \& Komagata, 1984). The strain contained meso-diaminopimelic acid as the wall diamino acid. The diagnostic sugars arabinose and galactose were present; glucose and ribose were also found. A menaquinone with a tetrahydrogenated-isoprenoid side chain of nine units $\left[\mathrm{MK}-9\left(\mathrm{H}_{4}\right)\right]$ was the principal isoprenoid quinone. Small amounts of MK- $8\left(\mathrm{H}_{4}\right)$ and MK-10 $\left(\mathrm{H}_{4}\right)$ were also found. Mycolic acids were not detected. The phospholipid pattern comprised phosphatidylcholine, phosphatidylethanolamine, phosphatidylmethylethanolamine, diphosphatidylglycerol, phosphatidylglycerol and phosphatidylinositol. Two unknown glycolipids were also found. The fatty acid pattern was composed mainly of terminally branched iso and anteiso fatty acids, but small amounts of diagnostic 10-methyl-branched fatty acids were found and no 2-OH fatty acids were detected. The chemical properties of strain SPE $10-1^{\mathrm{T}}$ are consistent with its assignment to the genus Saccharopolyspora.

Transmission electron microscopy of ultrathin sections of strain SPE $10-1^{\mathrm{T}}$ was performed as described previously (Pimentel-Elardo et al., 2003). Scanning electron microscopy was performed as described by Scheuermayer et al. (2006). Strain SPE $10-1^{\mathrm{T}}$ exhibited morphological properties characteristic of members of the genus Saccharopolyspora, forming extensively branched substrate mycelia that fragmented into rod-shaped elements (Fig. 1a).
Scanning electron microscopy showed hyphae bearing short chains of spores, as well as single spore cells (Fig. 1b). The spores were round to oval and the surface was smooth. Light microscopy of colonies confirmed the presence of spores in aerial mycelia (data not shown).

16S rRNA gene amplification, cloning and sequencing were performed according to the methods of Hentschel et al. (2001) using the universal primers 27f and 1492r (Lane, 1991). An almost complete $16 \mathrm{~S}$ rRNA gene sequence (1483 nt) was generated for the strain and it was compared with those of species of the genus Saccharopolyspora as its closest neighbours, as well as those from representatives of genera from the family Pseudonocardiaceae. The sequences were then aligned using CLUSTAL $\mathrm{W}$ and phylogenetic analysis was performed using the ARB software (Strunk et al., 2000). Phylogenetic tree construction was performed using the neighbour-joining algorithm with bootstrap values based on 100 replications (Fig. 2). Phylogenetic analysis revealed that strain SPE $10-1^{\mathrm{T}}$ had highest sequence similarity (96\%) with the type strain of S. gregorii and 93-95\% similarity with the type strains of all other species of this genus. Taken together, the phenotypic and genotypic data obtained in this study show clearly that strain SPE $10-1^{\mathrm{T}}$
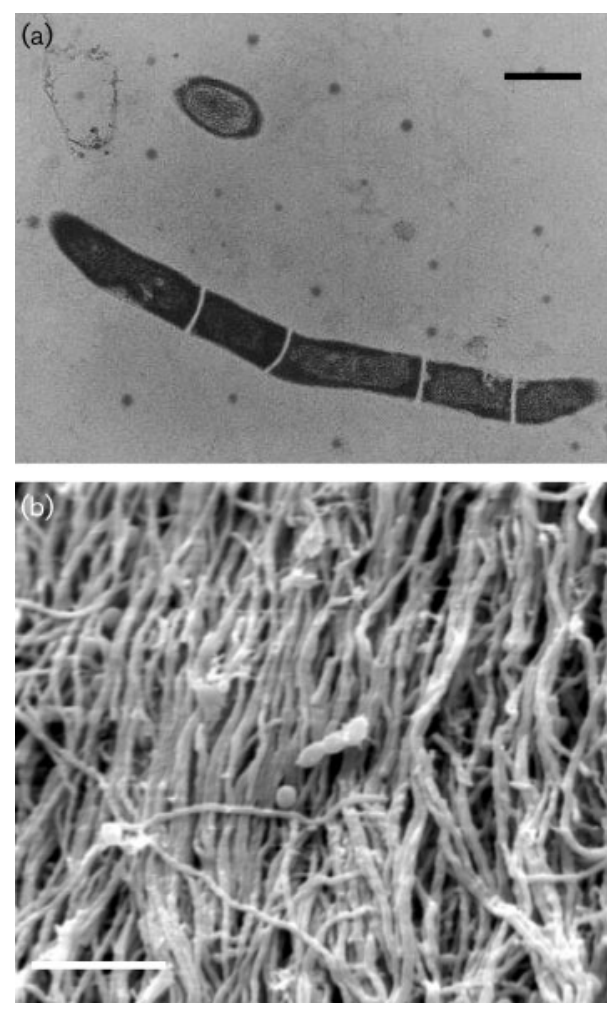

Fig. 1. Hyphae and spores of strain SPE $10-1^{\top}$ grown in $M 1$ broth (a, transmission electron microscopy, bar, $0.5 \mu \mathrm{m}$ ) and on $\mathrm{M} 1$ agar (b, scanning electron microscopy, bar, $5 \mu \mathrm{m}$ ) at $30{ }^{\circ} \mathrm{C}$ for 7 days. 


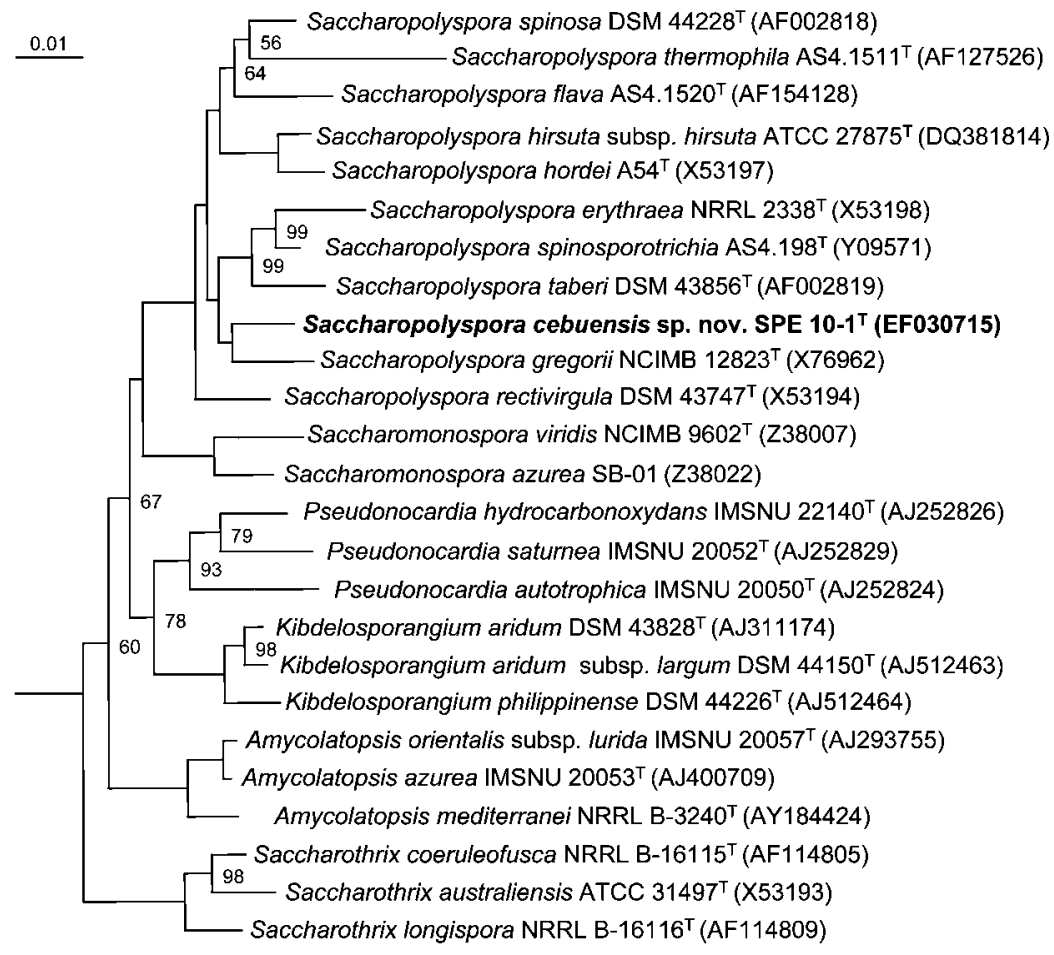

Fig. 2. Neighbour-joining tree based on nearly complete 16S rRNA gene sequences of strain SPE $10-1^{\top}$ and representative strains of members of the family Pseudonocardiaceae and related taxa. Escherichia coli (GenBank accession no. DQ360844) was used as outgroup (not shown). Numbers at the nodes indicate the levels of bootstrap support based on 100 resampled datasets; only values greater than $50 \%$ are shown. Bar, 0.01 substitutions per nucleotide position.

represents a novel and obligate marine species within the genus Saccharopolyspora.

\section{Description of Saccharopolyspora cebuensis sp. nov.}

Saccharopolyspora cebuensis (ce.bu'en.sis. N.L. fem. adj. cebuensis pertaining to the province of Cebu in the Philippines where the type strain was collected).

Cells are Gram-positive, aerobic and form extensively branched white mycelium fragmenting into rod-shaped elements and aerial hyphae bearing short chains of spores. Brown diffusible pigment is observed. Growth is possible at 15-37 ${ }^{\circ} \mathrm{C}$ and in ISP2 or M1 media containing $2.5-12.5 \%$ $\mathrm{NaCl}$ or $25-100 \%$ ASW. Does not grow anaerobically. Utilizes a variety of organic compounds such as glycerol, erythritol, D-arabinose, L-arabinose, D-ribose, D-xylose, Dadonitol, D-galactose, D-glucose, D-fructose, D-mannose, Lrhamnose, $N$-acetylglucosamine, amygdalin, aesculin, D-cellobiose, maltose, D-lactose, sucrose, trehalose, inulin, raffinose, starch, glycogen, gentiobiose, D-fucose, D-arabitol and potassium gluconate as sole carbon sources. Able to degrade tyrosine, but not adenine, casein, chitin or hypoxanthine. Negative for oxidase and nitrate reduction, but positive for catalase, alkaline phosphatase, esterase (C4), esterase lipase (C8), lipase (C14), leucine arylamidase, valine arylamidase, acid phosphatase, naphthol-ASBI-phosphohydrolase, $\alpha$-glucosidase, $N$-acetyl- $\beta$-glucosaminidase and $\alpha$-mannosidase. Cell wall contains mesodiaminopimelic acid as the diagnostic diamino acid. Whole cell hydrolysate contains galactose and arabinose. Major menaquinone is MK-9 $\left(\mathrm{H}_{4}\right)$. Lacks mycolic acids. Fatty acid pattern consists of iso, anteiso and 10-methyl-branched fatty acids. The DNA G $+\mathrm{C}$ content of the type strain is $72.6 \mathrm{~mol} \%$.

The type strain, SPE $10-1^{\mathrm{T}}\left(=\mathrm{DSM} 45019^{\mathrm{T}}=\mathrm{CIP} 109355^{\mathrm{T}}\right)$, was isolated from the Philippine sponge Haliclona sp.

\section{Acknowledgements}

We gratefully acknowledge J. Apurado and M. Rodriguez (U. San Carlos) for assistance during sponge collection, C. Gernert (U. Würzburg) for excellent technical assistance, and G. P. Concepcion (U. Philippines) and M. K. Harper (U. Utah) for sponge identification. Financial support was provided by the $b m b+f$ Center of Competence BIOTECmarin (03F0345E) to U.H. and the International Foundation for Science (F/3615-1) to S.P.-E.

\section{References}

Embley, T. M., Wait, R., Dobson, G. \& Goodfellow, M. (1987). Fatty acid composition in the classification of Saccharopolyspora hirsuta. FEMS Microbiol Lett 41, 131-135.

Goodfellow, M., Lacey, J., Athalye, M., Embley, T. M. \& Bowen, T. (1989). Saccharopolyspora gregorii and Saccharopolyspora hordei: two new actinomycete species from fodder. J Gen Microbiol 135, 2125-2139.

Gordon, R. E. (1967). The taxonomy of soil bacteria. In The Ecology of Soil Bacteria, pp. 293-321. Edited by T. R. G. Gray \& D. Parkinson. Liverpool: Liverpool University Press.

Hentschel, U., Schmid, M., Wagner, M., Fieseler, L., Gernert, C. \& Hacker, J. (2001). Isolation and phylogenetic analysis of bacteria with antimicrobial activities from the Mediterranean sponges Aplysina aerophoba and Aplysina cavernicola. FEMS Microbiol Ecol 35, 305-312. 
Korn-Wendisch, F., Kempf, A., Grund, E., Kroppenstedt, T. \& Kutzner, H. J. (1989). Transfer of Faenia rectivirgula Kurup and Agre 1983 to the genus Saccharopolyspora Lacey and Goodfellow 1975, elevation of Saccharopolyspora hirsuta subsp. taberi Labeda 1987 to species level, and emended description of the genus Saccharopolyspora. Int J Syst Bacteriol 39, 430-441.

Kroppenstedt, R. (1985). Fatty acid and menaquinone analysis of actinomycetes and related organisms. In Chemical Methods in Bacterial Systematics (Society for Applied Bacteriology Technical Series vol. 20), pp. 173-199. Edited by M. Goodfellow \& D. E. Minnikin. New York: Academic Press.

Labeda, D. P. (1987). Transfer of the type strain of Streptomyces erthyraeus (Waksman 1923) Waksman and Henrici 1948 to the genus Saccharopolyspora Lacey and Goodfellow 1975 as Saccharopolyspora erythraea sp. nov., and designation of a neotype strain for Streptomyces erythraeus. Int J Syst Bacteriol 37, 19-22.

Lacey, J. \& Goodfellow, M. (1975). A novel actinomycete from sugarcane bagasse: Saccharopolyspora hirsuta gen. et sp. nov. J Gen Microbiol 88, 75-85.

Lane, D. J. (1991). 16S/23S rRNA sequencing. In Nucleic Acid Techniques in Bacterial Systematics, pp. 115-175. Edited by E. Stackebrandt \& M. Goodfellow. Chichester: Wiley.

Lu, Z., Liu, Z., Wang, L., Qi, W. \& Goodfellow, M. (2001). Saccharopolyspora flava sp. nov. and Saccharopolyspora thermophila sp. nov., novel actinomycetes from soil. Int J Syst Evol Microbiol 51, 319-325.

Lyman, J. \& Fleming, R. H. (1940). Composition of sea water. J Mar Res 3, 134-146.

MacFaddin, J. F. (1980). Biochemical Tests for Identification of Medical Bacteria, 2nd edn. Baltimore, MD: Williams \& Wilkins.

Mertz, F. P \& Yao, R. C. (1990). Saccharopolyspora spinosa sp. nov. isolated from soil collected in a sugar mill rum still. Int J Syst Bacteriol 40, 34-39.

Mesbah, M., Premachandran, U. \& Whitman, W. B. (1989). Precise measurement of the $\mathrm{G}+\mathrm{C}$ content of deoxyribonucleic acid by highperformance liquid chromatography. Int J Syst Bacteriol 39, 159-167.
Mincer, T. J., Jensen, P. R., Kauffman, C. A. \& Fenical, W. (2002). Widespread and persistent populations of a major new actinomycete taxon in ocean sediments. Appl Environ Microbiol 68, 5005-5011.

Minnikin, D. E., Alshamaony, L. \& Goodfellow, M. (1975). Differentiation of Mycobacterium, Nocardia, and related taxa by thin-layer chromatographic analysis of whole-organism methanolysates. J Gen Microbiol 88, 200-204.

Minnikin, D. E., O’Donnell, A. G., Goodfellow, M., Alderson, G., Athalye, M., Schaal, A. \& Parlett, J. H. (1984). An integrated procedure for the extraction of bacterial isoprenoid quinones and polar lipids. J Microbiol Methods 2, 233-241.

Oppenheimer, C. H. \& ZoBell, C. E. (1952). The growth and viability of sixty-three species of marine bacteria as influenced by hydrostatic pressure. J Mar Res 11, 10-18.

Pimentel-Elardo, S., Wehrl, M., Friedrich, A. B., Jensen, P. R. \& Hentschel, U. (2003). Isolation of planctomycetes from Aplysina sponges. Aquat Microb Ecol 33, 239-245.

Scheuermayer, M., Gulder, T. A. M., Bringmann, G. \& Hentschel, U. (2006). Rubritalea marina gen. nov., sp. nov., a marine representative of the phylum 'Verrucomicrobia', isolated from a sponge (Porifera). Int J Syst Evol Microbiol 56, 2119-2124.

Shirling, E. B. \& Gottlieb, D. (1966). Methods for characterization of Streptomyces species. Int J Syst Bacteriol 16, 313-340.

Staneck, J. L. \& Roberts, G. D. (1974). Simplified approach to identification of aerobic actinomycetes by thin-layer chromatography. Appl Environ Microbiol 28, 226-231.

Strunk, O., Gross, O., Reichel, B. \& other authors (2000). ARB: a software environment for sequence data (http://www.mikro.biologie. tu-muenchen.de). Department of Microbiology, Technische Universität München, Germany.

Tamaoka, J. \& Komagata, K. (1984). Determination of DNA base composition by reversed-phase high-performance liquid chromatography. FEMS Microbiol Lett 25, 125-128.

Zhou, Z. H., Liu, Z. H., Qian, Y. D., Kim, S. B. \& Goodfellow, M. (1998). Saccharopolyspora spinosporotrichia sp. nov., a novel actinomycete from soil. Int J Syst Bacteriol 48, 53-58. 